E-waste disposal awareness among the Malaysian community
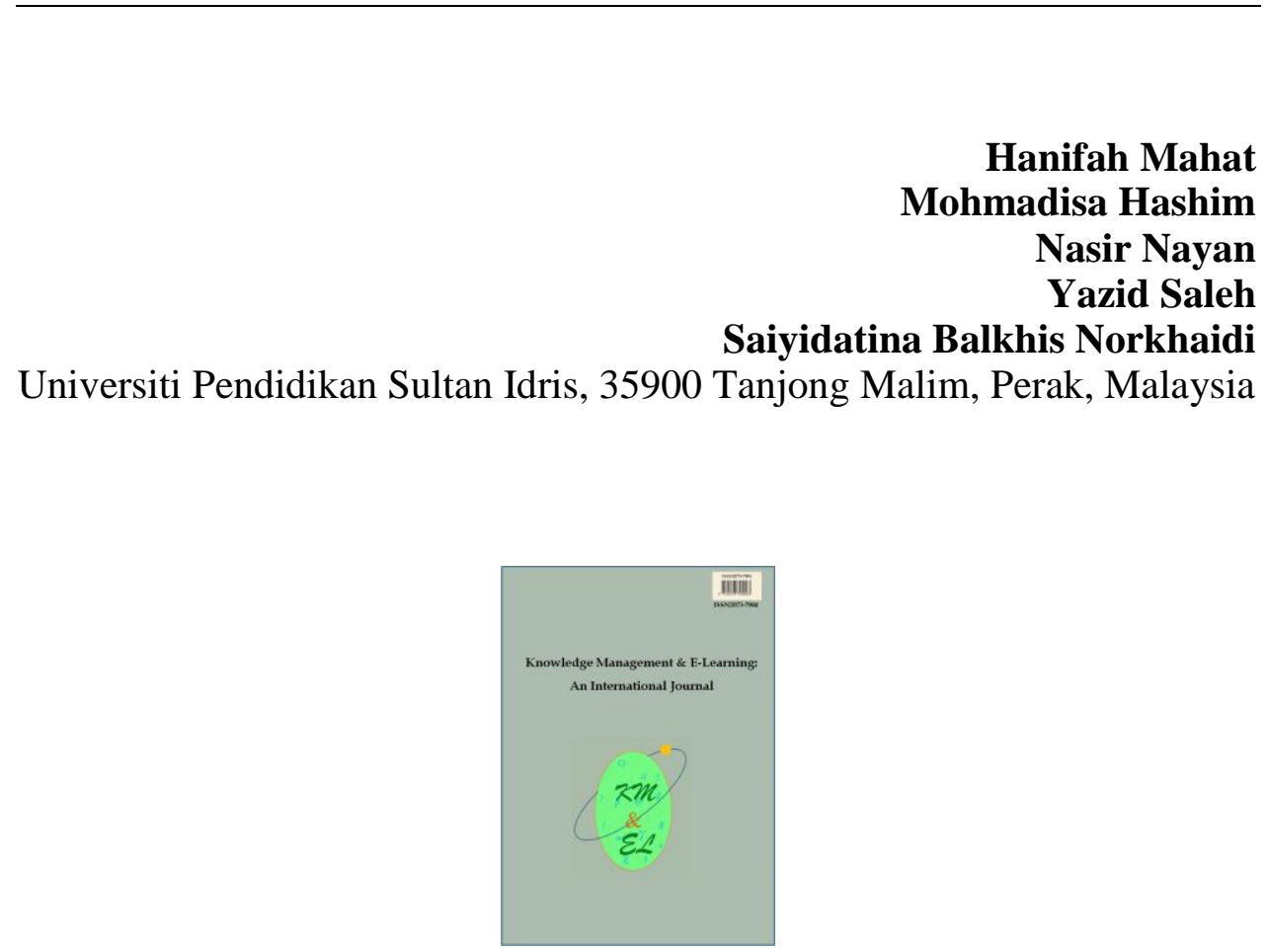

Knowledge Management \& E-Learning: An International Journal (KM\&EL) ISSN 2073-7904

Recommended citation:

Mahat, H., Hashim, M., Nayan, N., Saleh, Y., \& Norkhaidi, S. B. (2019). E-waste disposal awareness among the Malaysian community. Knowledge Management \& E-Learning, 11(3), 393-408. https://doi.org/10.34105/j.kmel.2019.11.021 


\title{
E-waste disposal awareness among the Malaysian
} community

\section{Hanifah Mahat*}

Department of Geography \& Environment

Faculty of Humanities

Universiti Pendidikan Sultan Idris, 35900 Tanjong Malim, Perak, Malaysia

E-mail: hanifah.mahat@fsk.upsi.edu.my

\section{Mohmadisa Hashim}

Department of Geography \& Environment

Faculty of Humanities

Universiti Pendidikan Sultan Idris, 35900 Tanjong Malim, Perak, Malaysia

E-mail:mohmadisa@fsk.upsi.edu.my

\section{Nasir Nayan}

Department of Geography \& Environment

Faculty of Humanities

Universiti Pendidikan Sultan Idris, 35900 Tanjong Malim, Perak, Malaysia

E-mail: nasir@fsk.upsi.edu.my

\section{Yazid Saleh}

Department of Geography \& Environment

Faculty of Humanities

Universiti Pendidikan Sultan Idris, 35900 Tanjong Malim, Perak, Malaysia

E-mail: yazid@fsk.upsi.edu.my

\section{Saiyidatina Balkhis Norkhaidi}

Department of Geography \& Environment

Faculty of Humanities

Universiti Pendidikan Sultan Idris, 35900 Tanjong Malim, Perak, Malaysia

E-mail: p20181001306@siswa.upsi.edu.my

*Corresponding author

\begin{abstract}
E-waste is any refuse created by discarded electronic devices and components as well as substances involved in their manufacture or use. Minimising the production of e-waste helps preserve resources and reducing the amount of energy drawn from the earth. One of the strategies to address this problem is raising e-waste disposal awareness in a sustainable manner among the community. This article aims to identify the level of e-waste disposal awareness among the Malaysia community. This study involved 500 people
\end{abstract}


from nine districts in Selangor, Malaysia by using stratified random sampling method. A questionnaire instrument was used to obtain feedback. The three variables of e-waste disposal awareness studied were e-waste disposal knowledge, e-waste disposal attitudes and e-waste disposal practices. Each variable was divided into three sub-variables; environmental, social and economic. The results showed that the respondents' e-waste disposal knowledge and e-waste disposal attitudes were at a high level, while their ewaste disposal practice were at a medium level. The findings and issues studied can be used as a reference for the government, non-governmental organisations, the authorities and the community when seeking to develop a more sustainable community life.

Keywords: E-waste disposal awareness; E-waste disposal knowledge; E-waste disposal attitudes; E-waste disposal practices; Malaysian

Biographical notes: Dr. Hanifah Mahat is a senior lecturer in the Department of Geography \& Environment, Faculty of Human Sciences at Universiti Pendidikan Sultan Idris (UPSI) Malaysia. She previously taught at senior high school level for 11 years, 6 years at teacher training institutes and joining the academic faculty at the University in 2014. Her major fields of research include Education for Sustainable Development and Human Geography.

Dr. Mohmadisa Hashim is a senior lecturer of Geography \& Environment, in the Faculty of Human Sciences at Universiti Pendidikan Sultan Idris (UPSI) Malaysia. His major fields of research include Physical Geography, Hydrology and Environmental Management.

Assoc. Prof. Dr. Nasir is a senior lecturer of Geography \& Environment, in the Faculty of Human Sciences at Universiti Pendidikan Sultan Idris (UPSI) Malaysia. His major fields of research include Geographic Information Systems (GIS), Remote Sensing, Remote Sensing, GIS Online, Business Information System, Physical Geography, Human Geography, Mangroves, Coral Reefs, Ecosystems, Ecology, Coastal, and Coastal Zones.

Assoc. Prof. Dr. Yazid Saleh is a senior lecturer of Geography \& Environment, in the Faculty of Human Sciences at Universiti Pendidikan Sultan Idris (UPSI) Malaysia. His major fields of research include sustainable Urban Geography, Urban Conservation Cultural and Heritage Tourism Urban Studies.

Ms. Saiyidatina Balkhis Norkhaidi is a doctoral candidate in the Faculty of Human Sciences at Universiti Pendidikan Sultan Idris (UPSI) Malaysia and also a Graduate Research Assistant. Her research interests include Carbon Literacy, Environmental Literacy and Environmental Numeracy.

\section{Introduction}

Advances in technology, particularly the development of electric and electronic appliances, are being made in Malaysia and provide a positive contribution to human life. However, a major issue is what do with electric and electronic appliances that can no longer be used or that are no longer needed. These are labelled as 'e-waste' as they need to be well-managed in order to ensure environmental sustainability. It has been demonstrated that, in recent years, the amount of e-waste has been increasing three times faster than previously (Puckett et al., 2002; United States Environmental Protection 
Agency (USEPA), 2011). An estimated 20 to 25 million tonnes of e-waste are generated each year worldwide (Abul Hasan et al., 2010) and the amount of e-waste will continue to increase every year in line with technological developments (Ibitz, 2012; Robinson, 2009). This means that the end-of-life of electric and electronic appliances has to be managed through a proper mechanism.

In Malaysia, e-waste management is still in its early stages, including the e-waste recycling system (Ahmad Faisal et al., 2014; Kalana, 2010). The main problem relating to e-waste in Malaysia is the poor attitude of Malaysians towards e-waste recycling (Ho et al., 2015; Kalana, 2010). In addition, there are still many flaws in the management and disposal control mechanisms for these appliances, despite the increase in the usage of electrical and electronic appliances, in line with population growth.

At the moment, solid waste management, including e-waste, in Malaysia is very challenging and often emerges as a national issue (Malaysia Department of Environment, 2013). E-waste management facility toward sustainable source should be considered (Fatihah et al., 2014). Most landfills in Malaysia are now facing their expected lifetime. This is due to the amount of solid waste being generated, including e-waste, increasing in line with population growth. In fact, the decreasing lifespan of electrical and electronic products has added to the accumulation of e-waste in Malaysia. These electrical and electronic appliances contain toxins such as lead, mercury and cadmium that are harmful when released into the environment, contaminating water, soil and air. In fact, e-waste also contains polychlorinated biphenyls (PCBs) that can cause carcinogenic effects in humans, and thus can be harmful to human health (Muaz \& Mohamed, 2008).

E-waste disposal requires a complex and different management system from that of daily solid waste management. In Malaysia, electronic waste must comply with the Environmental Quality Act 1974, which is administered by the Department of Environment. Electronic waste is classified as scheduled waste under the code SW 110, which is managed by the Department of Environment. This means that e-waste cannot be disposed together with other solid waste. The question then is to what extent people know and aware about the proper management of e-waste and the maximisation of environmental sustainability in a state such as Selangor which has provided e-waste recycling spots and where e-waste information has been disseminated by the Department of Environment and other non-governmental organisations. However, there are significantly less on psychometric research in term of e-waste disposal awareness among Malaysian's community. Therefore, what is the level of e-waste sustainable disposal awareness among by Malaysians? To what extent do people know and be aware about the proper management of e-waste in Malaysia? Thus, this research in this article is using survey method since it is useful in describing the characteristics of a large population. The collection of information on the actual knowledge, attitudes and practices of the public in managing e-waste is thus a necessary part of the process of improving information dissemination and also of finding the constraints imposed by the community on the implementation of more sustainable e-waste management awareness. The structure of this article is divided into six section, first is introduction that addressing on e-waste globally and e-waste disposal awareness in the community on second section. Third section will explain on method of study, study findings and discussion in fourth section while conclusion and references in the final section. 


\section{E-waste disposal awareness in the community}

The study of individual awareness of e-waste management practice plays an important role in the process of determining whether or not the individual understands and knows about e-waste management. Awareness is defined as the understanding of other activities in the context of own self activities (Dourish \& Bellotti, 1992). Merikle (1984) define awareness into two different contrasted. One definition, used in recent masked-prime studies, is objective and equates awareness with the ability to make forced-choice decisions above a chance level of performance. While, the second definition, that was proposed by Henley (1984), is subjective and simply equates awareness with self-reports indicating that an observer "consciously sees" a stimulus. It is concluded that a better objective measure of awareness is needed to distinguish the subjective states of "seeing" and "notseeing" a stimulus. In term of environment awareness, according to Starke (1990), many have failed to translate awareness into commitment and although many individuals have knowledge of the environment, but they still have an irresponsible attitude towards it.

In the context of this study, e-waste management awareness in the community was defined into three main elements: knowledge, attitudes and practices. According to Sabouhi et al. (2011) on their research findings, they indicate that there was a relationship between awareness toward knowledge, attitude and practice where knowledge becoming main factors in the smart city of the future (Salerno, Nunziante, \& Santoro, 2014). Based on the early knowledge, attitudes, practices (KAP) model introduced by Schwartz (1976), the model emphasis the existence of awareness based on three elements: knowledge, attitudes and practices (Schwartz, 1976) (Fig. 1). KAP surveys were first developed in the 1950 s and extensively used in many countries to social science research. The KAP studies are more cost-effective and conserve resources more than other social research methods, because they are tightly focused and limited in scope (Eckman \& Walker, 2008). KAP surveys are now a widely used methodology for studying human behaviour when affected by an environmental problem.

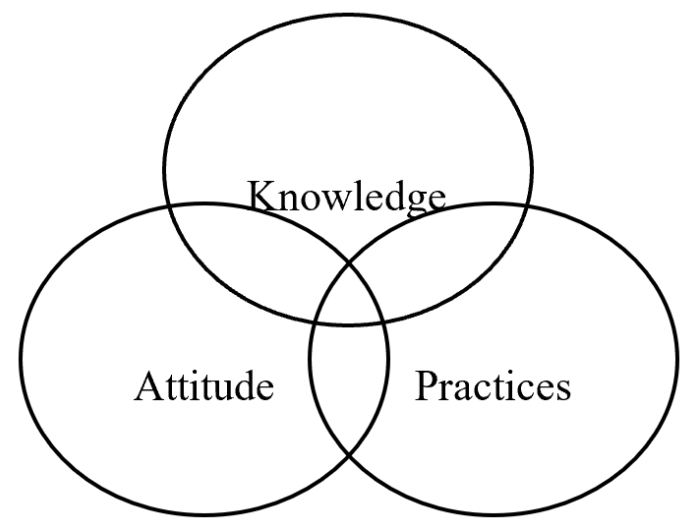

Fig. 1. Knowledge, attitudes, practices (KAP) model, adapted from Schwartz (1976)

Each element is studied based on three domains of sustainability which are environmental, social and economic (Barbier, 1987; Pinfield, 1996; Wright \& Nebel, 2005; Shahrom et al., 2009; Muukkonen et al., 2013; Hanifah et al., 2016) (Fig. 2). 


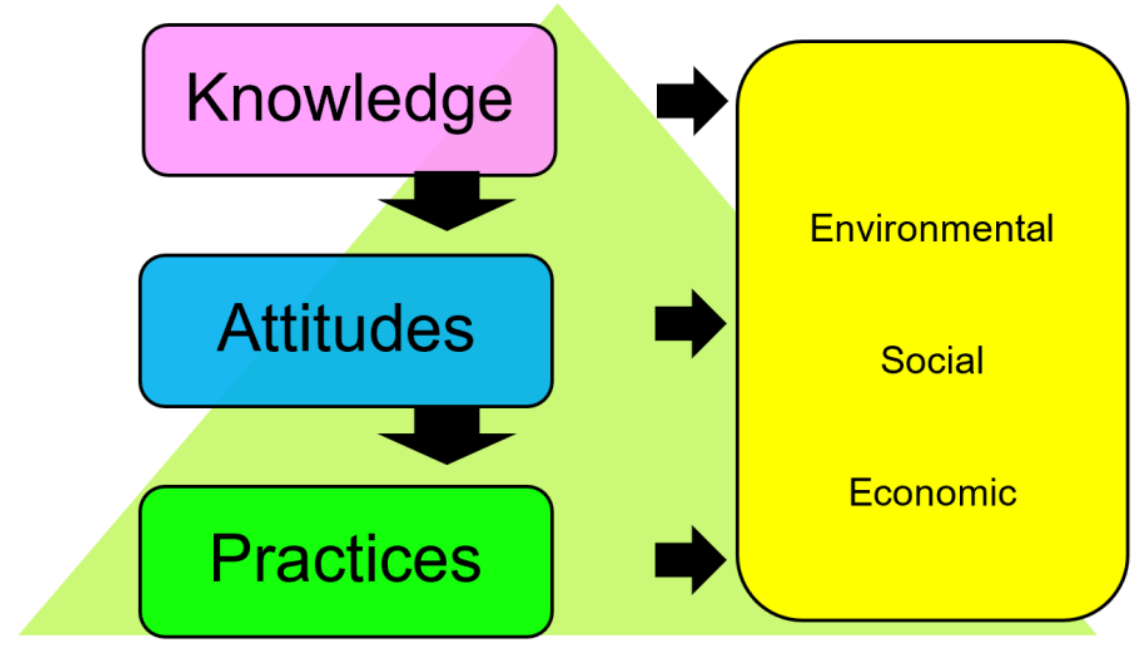

Fig. 2. Conceptual framework

Therefore, the awareness elements, which are knowledge, attitudes and practices of e-waste management, are important in order to establish a cost-effective and environmentally friendly management system, as stated by Norazli et al. (2015). There are a number of foreign countries, such as Jordan, Nigeria, India, China, Spain, Iraq and the Philippines, that have conducted this study and their results showed that the public's level of knowledge of e-waste management was different in certain areas. For example, a study by Tarawneh and Saidan (2013) in Jordan showed that households' level of knowledge of e-waste was low, indeed almost none of the respondents knew about ewaste. In addition, a study by Okoye and Odoh (2014) in Anambra, Onitsha, Africa country also showed that knowledge of government rules about e-waste management and the harmful effects of electronic components on the health of the population was still worryingly low, even though Onitsha was the largest market for importing new and used electronic products in West Africa. The survey conducted in Delhi by Kwatra, Pandey, and Sharma (2014) revealed that significant fraction of middle-class population is still unaware of the issue; however, on getting the information they were able to link the impacts of improper management of e-waste with detrimental health outcomes.

However, not all countries demonstrated a lack of e-waste awareness amongst their publics. For example, in Ningbo, China, most of the respondents possessed knowledge of e-waste management in terms of recycling and $64 \%$ of respondents were aware of environmental labelling. This could be seen when the consumers disposed of electronic waste, as they separated the materials according to the labelled waste container (Huang, Zhang, \& Deng, 2006). Even though the studies by Okoye and Odoh (2014), as well as Sivathanu (2016), showed that consumers had knowledge of e-waste management, it was found that when their understanding was tested thoroughly, most of the respondents were unable to give the correct overview and examples.

The scenario that is found abroad also happens in Malaysia. Most studies have shown that the Malaysian public has a high level of e-waste knowledge, but when questioned further about e-waste management, the answers of the Malaysian public were unsatisfying. This can be seen in the studies by Afroz et al. (2012) and Akhtar, Masud, and Afroz (2014) in the city of Kuala Lumpur, whose findings showed that respondents were aware that electrical and electronic appliances had created problems for the 
environment. A study by Kalana (2010), on the level of knowledge and awareness amongst the public in Shah Alam, also showed that respondents had in-depth knowledge about e-waste. However, the researchers found that most respondents did not know the correct ways of disposing of e-waste. This statement is also supported by Nur Sumaiyyah, Gautam, and Mohd Badruddin (2015), who argued that consumers were not aware of the right way of treating e-waste, even though local authorities, for example those in Selangor, had implemented the separation of solid waste, starting on 1st September 2015, pursuant to the rules established by the Solid Waste and Public Cleansing Management Act 2007 (Act 672) (Department of National Solid Waste Management, 2015).

Thus, research on e-waste disposal awareness in this community is important in order to identify those issues and problems that influence awareness, in the context of knowledge, attitudes and practices. The issues and problems studied can be used as a reference for the government, non-governmental organisations, the authorities and the community when seeking to develop a more sustainable community life.

\section{Method}

The design used in this study is quantitative research using the questionnaire technique as an instrument. This type of design is suitable for a population sample that has been predetermined, at a specific point in time (single point in time) (Bhattacherjee, 2012; Zainudin, 2010), even if the data collection period takes more than a day or a few weeks (Norizan, Nordin, \& Mohd Ali, 2010). In the context of this study, a questionnaire survey was chosen to obtain data on e-waste management knowledge, e-waste management attitudes and e-waste management practices. The surveys have been conducted by field researchers at designated locations as well as public focus areas in Selangor. Respondent selection is random where respondents who are able to read are required to answer the given survey while respondents who are relatively old are assisted by field researchers using questioning techniques.

\subsection{Study location}

Study location involved the consumer community living in Selangor. The state of Selangor consists of nine districts, namely Petaling, Hulu Langat, Klang, Gombak, Kuala Langat, Sepang, Kuala Selangor, Hulu Selangor and Sabak Bernam (Fig. 3). Selangor was selected as a study area due to the increase in exposure to information about e-waste through public and private agencies since 2016. This means that communities in Selangor had been given information, and the opportunity for awareness, earlier than people in other states. On this basis, Selangor was seen as a suitable subject for the study of public e-waste knowledge, attitudes and practices.

\subsection{Population and study samples}

Sampling methods used in this study included stratified random sampling for the study area and simple random sampling for the selection of respondents by districts in Selangor. The total population of nine districts was 3,947,527 (Department of Statistics Malaysia, 2010). Out of that number, the minimum recommended sample size is 387 people, based on the table of Krejcie and Morgan (1971). Thus, this study determined that 500 respondents should be sought and the breakdown of samples by district is shown in Table 1. There are nine districts in Selangor. The number of respondents will be drawn from among the communities living in the districts and must be a head of household. A 
summary of the population and respondent sample numbers can be found in Table 1 . Hypotheses generation. Based on the case information and relevant domain knowledge, the learner can make hypotheses, and add them as hypothesis nodes into the argument map. Where appropriate, the hypothesis nodes can be generated based on relevant concepts from the concept map.

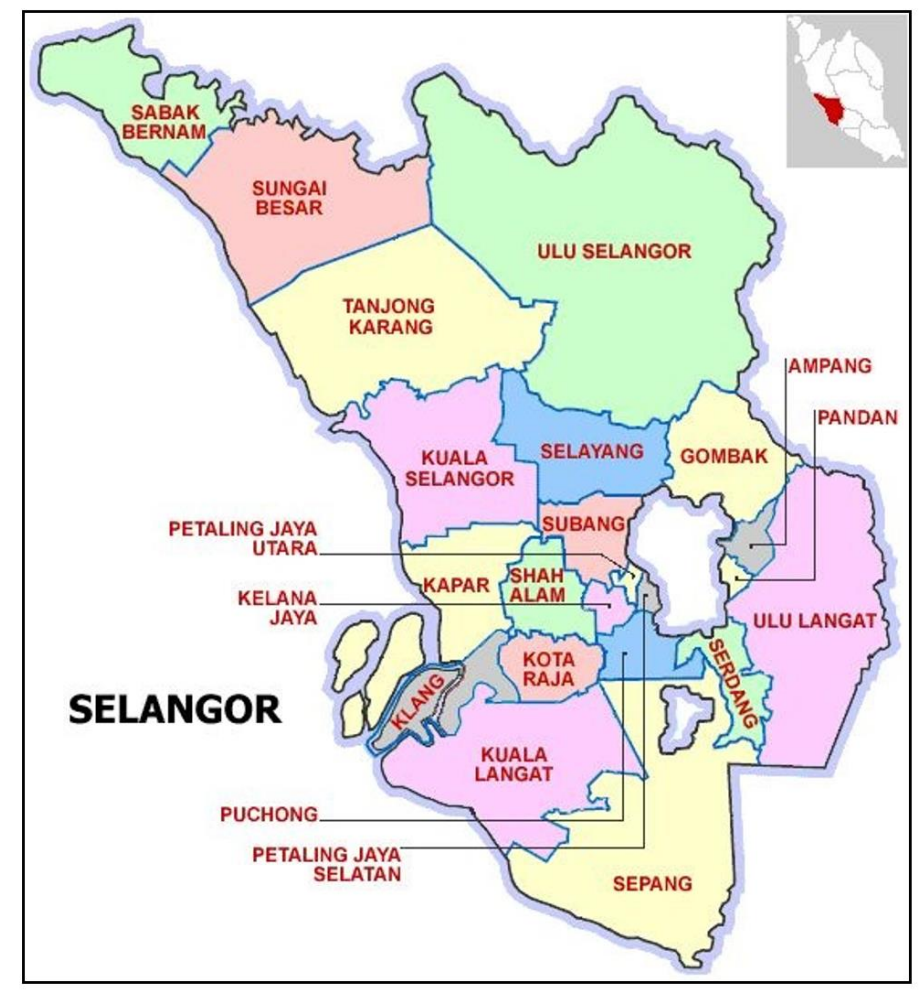

Fig. 3. Selangor district, adapted from Selangor District Government Portal (2016)

Table 1

Number of respondents by districts in Selangor

\begin{tabular}{lcccc}
\hline District & Population & Percentage $(\%)$ & Sampling Calculation & Sample \\
\hline Petaling & $1,181,034$ & 30 & $1,181,034 \times 30 \%$ & 150 \\
Hulu Langat & 865,514 & 22 & $865,514 \times 22 \%$ & 110 \\
Klang & 648,918 & 16 & $648,918 \times 16 \%$ & 82 \\
Gombak & 553,410 & 14 & $553,410 \times 14 \%$ & 70 \\
Kuala Langat & 189,983 & 4 & $189,983 \times 4 \%$ & 24 \\
Sepang & 97,896 & 3 & $97,896 \times 3 \%$ & 12 \\
Kuala Selangor & 157,288 & 4 & $157,288 \times 4 \%$ & 20 \\
Hulu Selangor & 142,771 & 4 & $142,771 \times 4 \%$ & 18 \\
Sabak Bernam & 110,713 & 3 & $110,713 \times 3 \%$ & 14 \\
Total & $3,947,527$ & 100 & & 500 \\
\hline
\end{tabular}




\subsection{Study instrument}

A questionnaire was used as an instrument in this study. The questionnaire items were divided into six sections; background of the respondents, e-waste disposal method of the respondents, e-waste management knowledge, e-waste management attitudes, e-waste management practices and open questions. The content information of each variable and the measurement scale of each variable of this study are described in Table 1. The measurement scale of the items for each variable uses the 5-point Likert's scale, which for the variables of e-waste management knowledge and e-waste management attitudes is $1=$ strongly disagree, 2 -disagree, 3 -somewhat disagree, 4 -agree and 5-strongly agree. For the variables of e-waste management practices, the Likert scale used is $1=$ never, 2sometimes, 3-occasionally, 4-always and 5-very frequently.

Table 2

Study instrument/ questionnaire

\begin{tabular}{|c|c|c|c|c|}
\hline Part & Details & Variables & $\begin{array}{l}\text { Number } \\
\text { of items }\end{array}$ & Source of items \\
\hline \multirow{5}{*}{ A } & \multirow{5}{*}{$\begin{array}{l}\text { Respondent } \\
\text { Background }\end{array}$} & Area & 9 & \multirow{5}{*}{$\begin{array}{l}\text { Built according to the } \\
\text { study itself }\end{array}$} \\
\hline & & Location & 2 & \\
\hline & & Ages & 5 & \\
\hline & & Gender & 2 & \\
\hline & & Etnic & 6 & \\
\hline B & $\begin{array}{l}\text { Method of E- } \\
\text { waste Disposal }\end{array}$ & $\begin{array}{l}\text { Based on } 27 \\
\text { electrical and } \\
\text { electronic equipment }\end{array}$ & 27 & $\begin{array}{l}\text { Built according to the } \\
\text { study itself }\end{array}$ \\
\hline \multirow{3}{*}{$\mathrm{C}$} & \multirow{3}{*}{$\begin{array}{l}\text { Knowledge of } \\
\text { E-Waste } \\
\text { Management }\end{array}$} & Environment & 7 & \multirow{3}{*}{$\begin{array}{l}\text { Built with custom and } \\
\text { refers to the study of } \\
\text { Okoye and Odoh (2014), } \\
\text { Sivathanu (2016), } \\
\text { Echegaray and Hansstein } \\
\text { (2017) and Akhtar, Masud, } \\
\text { and Afroz (2014) }\end{array}$} \\
\hline & & Social/ Health & 9 & \\
\hline & & Economy & 6 & \\
\hline \multirow{3}{*}{$\mathrm{D}$} & \multirow{3}{*}{$\begin{array}{l}\text { Attitudes of E- } \\
\text { Waste } \\
\text { Management }\end{array}$} & Environment & 5 & \multirow{3}{*}{$\begin{array}{l}\text { Built with custom and } \\
\text { refers to the study of } \\
\text { Echegaray and Hansstein } \\
\text { (2017), Afroz et al. (2012) } \\
\text { and Akhtar, Masud, and } \\
\text { Afroz (2014) }\end{array}$} \\
\hline & & Social/ Health & 7 & \\
\hline & & Economy & 5 & \\
\hline \multirow{3}{*}{$\mathrm{E}$} & \multirow{3}{*}{$\begin{array}{l}\text { Practices of E- } \\
\text { Waste } \\
\text { Management }\end{array}$} & Environment & 9 & \multirow{3}{*}{$\begin{array}{l}\text { Built with custom and } \\
\text { refers to the study of } \\
\text { Okoye and Odoh (2014), } \\
\text { Sivathanu (2016), } \\
\text { Echegaray and Hansstein } \\
\text { (2017), Akhtar, Masud, } \\
\text { and Afroz (2014) and Ho } \\
\text { et al. (2015) }\end{array}$} \\
\hline & & Social/ Health & 6 & \\
\hline & & Economy & 7 & \\
\hline $\mathrm{F}$ & Open Question & Comment & 2 & $\begin{array}{l}\text { Built according to the } \\
\text { study itself }\end{array}$ \\
\hline
\end{tabular}


Table 3 also shows that all three variables demonstrate the same Cronbach's alpha reliability values above 0.7 , which is at an acceptable level (Lance, Butts, \& Michels, 2006). The study instrument also went through a content experts' validity review by five academics from Universiti Pendidikan Sultan Idris. As for face validity, five local residents of Hulu Bernam, Selangor were involved in testing the suitability and understanding of the questionnaire contents.

Table 3

Reliability item value

\begin{tabular}{llcc}
\hline \multicolumn{1}{c}{ Variables } & Sub Variables & $\begin{array}{c}\text { Number of } \\
\text { Items }\end{array}$ & $\begin{array}{c}\text { Alpha } \\
\text { Cronbach } \\
\text { Value }\end{array}$ \\
\hline Knowledge of E- & Environment & 7 & 0.732 \\
Waste Management & Social/ Health & 9 & 0.881 \\
& Economy & 6 & 0.857 \\
Attitudes of E-Waste & Environment & 5 & 0.712 \\
Management & Social/ Health & 7 & 0.786 \\
& Economy & 5 & 0.754 \\
Practices of E-Waste & Environment & 9 & 0.818 \\
Management & Social/ Health & 6 & 0.849 \\
& Economy & 7 & 0.721 \\
\hline
\end{tabular}

\section{Findings and discussion}

\subsection{Background of the respondents}

The discussion of the study findings is divided into two parts, namely respondents' background and respondents' level of e-waste disposal awareness. On the respondents' background, the study findings discuss location, age, gender, and race of the respondents. On the level of e-waste disposal awareness, the findings are divided according to the study variables, which are e-waste disposal knowledge, e-waste disposal attitudes and ewaste disposal practices.

Table 4 shows the background of 500 respondents living in Selangor. In terms of location, 307 respondents $(61.4 \%)$ lived in urban areas and the remaining $193(38.6 \%)$ lived in rural areas. Next, the findings on respondents' age show that the largest group of respondents involved in this study were within the age range of 21 to 30 years old, representing $37 \%$ of total respondents. They were followed by the age range of 41 to 50 years old $(23.6 \%), 31$ to 40 years old $(22.4 \%)$, under 20 years old $(6.8 \%)$ and 51 years old and above $(10.2 \%)$. The numbers of male and female respondents were almost equal, with 257 males $(51.4 \%)$ and 243 females (48.6\%). The findings on the last piece of background information, respondents' race, showed that the majority of respondents involved in this study were Malays, with a total of 451 (90.2\%), followed by 30 Chinese, 9 people of other races, 4 each for Indians and natives of Sarawak, and 2 natives of Sabah. 
Table 4

Respondent background

\begin{tabular}{llcc}
\hline & Respondent Background & N & \% \\
\hline Location & Urban areas & 307 & 61.4 \\
& Rural areas & 193 & 38.6 \\
Age & Total & $\mathbf{5 0 0}$ & $\mathbf{1 0 0}$ \\
& Below 20 years old & 34 & 6.8 \\
& 21 to 30 years old & 185 & 37.0 \\
& 31 to 40 years old & 112 & 22.4 \\
& 41 to 50 years old & 118 & 23.6 \\
Gender & Above 50 years old & 51 & 10.2 \\
& Total & $\mathbf{5 0 0}$ & $\mathbf{1 0 0}$ \\
& Male & 257 & 51.4 \\
Race & Female & 243 & 48.6 \\
& Total & $\mathbf{5 0 0}$ & $\mathbf{1 0 0}$ \\
& Malay & 451 & 90.2 \\
& Chinese & 30 & 6.0 \\
& Indian & 4 & 0.8 \\
& Natives of Sabah & 2 & 0.4 \\
& Natives of Sarawak & 4 & 0.8 \\
& Others & 9 & 1.8 \\
& Total & $\mathbf{5 0 0}$ & $\mathbf{1 0 0}$ \\
\hline
\end{tabular}

\subsection{E-waste disposal methods of the respondents}

Fig. 4 shows e-waste disposal methods based on different electrical and electronic appliances. Among the appliances listed are refrigerator, air conditioner, washing machine, ceiling fan, iron, water heater, blender, oven/microwave, hair dryer, desk fan, vacuum cleaner, cake mixer, computer, laptop, mobile phone, telephone, photocopy machine, scanner, fax machine, internet modem, television, Astro decoder, radio, stereo, DVD player, light bulb and fluorescent lamp. The majority of respondents practise the ewaste disposal method of selling them as used appliances $(25 \%)$. The second most chosen practise is to switch it with a new one (20\%), followed by the third method which is sending it to the recycling centre $(17 \%)$. The fourth method is keeping them in a store/outdoors $(11 \%)$, the fifth method is donating them to charities, schools or others (9\%), the sixth method is throwing them out with other trash $(8 \%)$, the seventh method is giving them to friends or relatives $(5 \%)$, and the last and least practised method is selling them to classic/old item collectors $(5 \%)$.

\subsection{Level of e-waste disposal awareness in the community}

The response of respondents regarding e-waste disposal awareness in the community is based on three variables: e-waste disposal knowledge, e-waste disposal attitudes and ewaste disposal practices. Each of these variables has been identified by its mean value, standard deviation and level. The level categorisation is made based on the scale in Table 5. Level categorization was based on the level range calculation between mean higher 
score and lower mean score $(5-1=4)$ and divided into three for three categories (4 $3=$ 1.33 ) by Landell (1997). Lower levels are between 1.00 to $2.33(1.00+1.33)$, medium level is between 2.34 to $3.66(2.34+1.33)$ while higher level are between 3.67 to 5.00 $(3.67+1.33)$.

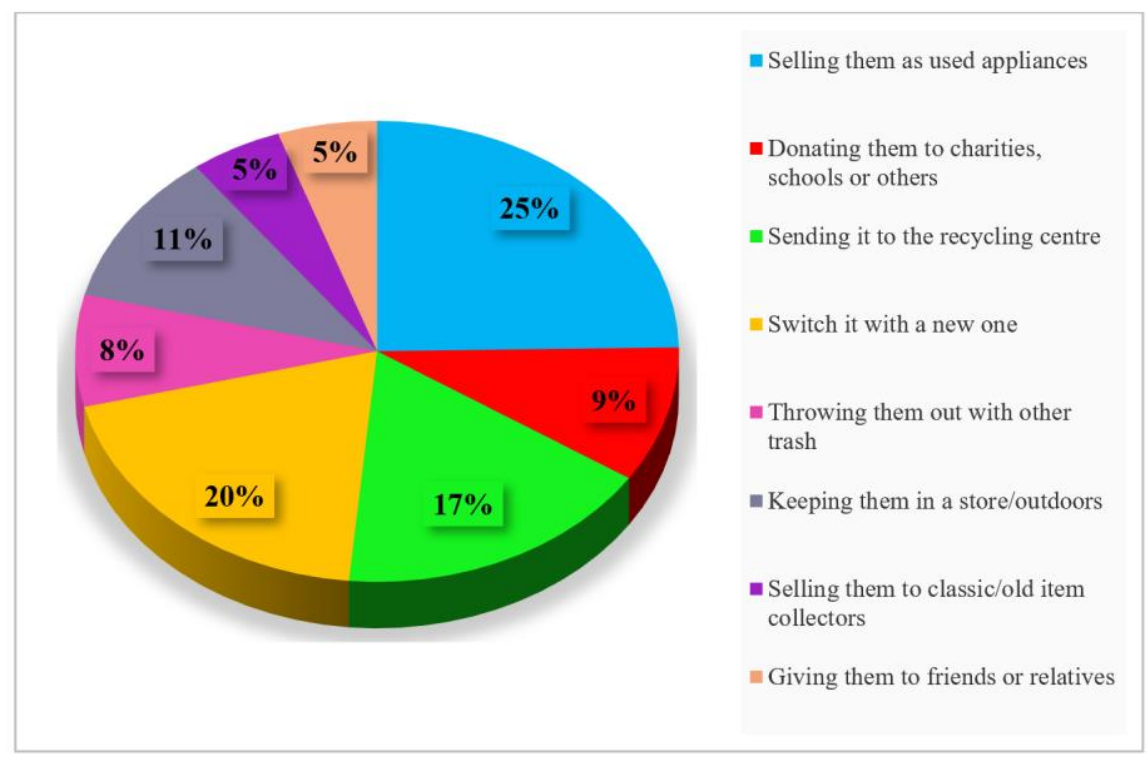

Fig. 4. E-waste disposal methods of the respondents

Table 5

Level of mean scale ad criteria

\begin{tabular}{cc}
\hline Mean Scale & Criteria \\
\hline 1.00 to 2.33 & Poor \\
2.34 to 3.66 & Medium \\
3.67 to 5.00 & High \\
\hline
\end{tabular}

Note. adapted from Landell (1997)

Table 6 shows e-waste disposal knowledge levels among the respondents and subvariables, divided into three parts: environmental, social and economic. The results show that the overall level of variables and sub-variables are at the high end, within the range of 3.34 to 5.00 of mean value. This indicates that the level of knowledge regarding ewaste disposal in the community is very good and satisfactory. This finding is consistent with the studies by Afroz et al. (2012) and Akhtar et al. (2014) in the city of Kuala Lumpur, which found that the respondents do know that electrical and electronic appliances have created problems for the environment. Similarly, a study by Kalana (2010) regarding the level of knowledge and awareness among the public in Shah Alam also showed that the respondents had in-depth knowledge about e-waste. This finding however, is not in line with the study by Okoye and Odoh (2014) in Africa, which demonstrated that the e-waste knowledge of its respondents was still low. Similarly, the findings by Echegaray and Hansstein (2017) indicated that e-waste knowledge of the community varied based on income levels, so that high-income individuals were more likely to know about e-waste than low-income groups. This proves that information on e- 
waste in general has been received and acknowledged by the public in Malaysia, especially in Selangor.

Table 6

Level of e-waste disposal knowledge

\begin{tabular}{lcccccccccc}
\hline \multirow{2}{*}{$\begin{array}{l}\text { Variables / } \\
\text { sub-variables }\end{array}$} & \multicolumn{2}{c}{ Poor } & \multicolumn{9}{c}{ Medium } & \multicolumn{2}{c}{ High } & Mean & SD & Mean \\
\hline Knowledge & $\mathbf{N}$ & $\mathbf{\%}$ & $\mathbf{N}$ & $\mathbf{\%}$ & $\mathbf{N}$ & $\mathbf{\%}$ & & & \\
\hline - Environment & 13 & 2.6 & 149 & 29.8 & 338 & 67.6 & 3.80 & 0.56 & High \\
- Social/ Health & 22 & 4.4 & 212 & 42.4 & 266 & 53.2 & 3.68 & 0.63 & High \\
- Economy & 8 & 1.6 & 138 & 27.6 & 354 & 70.8 & 4.00 & 0.64 & High \\
\hline
\end{tabular}

Table 7 shows e-waste disposal attitudes among the respondents in Selangor. The variables of attitude in this study were also divided into three parts of sustainability domain which are environmental, social and economic. The findings show that the overall level of these variables and sub-variables are also high. This clearly shows that the attitude of the Selangor community towards e-waste disposal is at a good and satisfying level. This is totally contrary to the previous studies by Ho et al. (2015) and Kalana (2010) which stated that the attitude of Malaysians towards e-waste recycling was still poor.

\section{Table 7}

Level of e-waste disposal attitudes

\begin{tabular}{lccccccccc}
\hline \multirow{2}{*}{$\begin{array}{l}\text { Variables / } \\
\text { sub-variables }\end{array}$} & \multicolumn{1}{c}{ Poor } & \multicolumn{9}{c}{ Medium } & \multicolumn{2}{c}{ High } & Mean & SD & Mean \\
& $\mathbf{N}$ & $\mathbf{\%}$ & $\mathbf{N}$ & $\mathbf{\%}$ & $\mathbf{N}$ & $\mathbf{\%}$ & & & \\
\hline Attitudes & 1 & 0.2 & 120 & 24.0 & 379 & 75.8 & 3.91 & 0.41 & High \\
- Environment & 1 & 0.2 & 135 & 27.0 & 364 & 72.8 & 3.93 & 0.50 & High \\
- Social/ Health & 4 & 0.8 & 123 & 24.6 & 373 & 74.6 & 3.88 & 0.48 & High \\
- Economy & 5 & 1.0 & 168 & 33.6 & 327 & 65.4 & 3.93 & 0.63 & High \\
\hline
\end{tabular}

Table 8

Level of e-waste disposal practices

\begin{tabular}{|c|c|c|c|c|c|c|c|c|c|}
\hline \multirow{3}{*}{$\begin{array}{l}\text { Variables / } \\
\text { sub-variables }\end{array}$} & \multirow{2}{*}{\multicolumn{2}{|c|}{ Poor }} & \multicolumn{4}{|c|}{ Level } & \multirow{3}{*}{ Mean } & \multirow{3}{*}{ SD } & \multirow{3}{*}{ Mean } \\
\hline & & & \multicolumn{2}{|c|}{ Medium } & \multicolumn{2}{|c|}{ High } & & & \\
\hline & $\mathbf{N}$ & $\%$ & $\mathbf{N}$ & $\%$ & $\mathbf{N}$ & $\%$ & & & \\
\hline Practices & 91 & 18.2 & 318 & 63.6 & 91 & 18.2 & 3.01 & 0.68 & Medium \\
\hline - Environment & 117 & 23.4 & 301 & 60.2 & 82 & 16.4 & 3.00 & 0.75 & Medium \\
\hline - Social/ Health & 152 & 30.4 & 264 & 52.8 & 84 & 16.8 & 2.93 & 0.88 & Medium \\
\hline - Economy & 90 & 18.0 & 293 & 58.6 & 117 & 23.4 & 3.08 & 0.73 & Medium \\
\hline
\end{tabular}


Table 8 shows the level of e-waste disposal practices among the respondents in Selangor, which is divided into three parts of sustainability domain which are environmental, social and economic, similar to the variables for e-waste disposal knowledge and attitudes. The findings show that the overall level of variables and subvariables of e-waste disposal practices are medium, in general. There is a difference between the findings of the level of knowledge and attitudes when compared to e-waste disposal practices. It shows that the community in Selangor is still at the middle level in terms of practising sustainable e-waste disposal. This is because most of the respondents did not know and were not aware of the correct practices for treating and disposing of ewaste (Kalana, 2010; Nur Sumaiyyah et al., 2015).

Overall, it has been discovered that e-waste management awareness among the community in Selangor is getting better and is still in the process of improving. This is in line with the findings of Ho et al. (2015), who studied awareness of e-waste management practices in Malacca households and found that the development of awareness of households towards e-waste recycling was still at an early stage. Similarly, the findings by Chibunna et al. (2012), in a study of students at Universiti Kebangsaan Malaysia (UKM), showed that awareness of e-waste varied according to the location in which respondents lived: those living in urban areas had a higher level of awareness than respondents living in rural areas due to the limitations in term of information. However, e-waste disposal awareness in the community is very closely related to the three main elements that have been specified in the KAP Model, which are knowledge, attitudes and practices, as described in the introduction of the article. In conclusion, it was found that knowledge and attitudes give effect to e-waste disposal practices even it still at a medium level. Therefore, in order to develop more practical e-waste disposal practices and thus sustain the environment, public exposure to e-waste issues should be improved through awareness campaigns as well as through the deployment of education agents at an early stage of life, namely in primary and secondary schools (Kalana, 2010; Hanifah et al., 2016).

\section{Conclusion}

The results of this study show that the e-waste disposal method that is often practised by respondents is to sell such goods as used appliances. This is followed by swapping them with new appliances, dropping them off at a recycling centre, keeping them in a store/outdoors, donating to charities, schools or others, disposing of them together with other trash, giving them to friends or relatives, and lastly, the method least used by the respondents is to sell them to classic/old item collectors. As for the findings regarding levels, it was found that e-waste management knowledge and attitudes in the community are at a high level while e-waste disposal practices still at medium level. This demonstrates the public's knowledge and attitude towards e-waste disposal awareness is good but still less practicing in everyday life. Early exposure to information regarding ewaste by the government and private agencies in Selangor is the factor that helped in improving e-waste management knowledge and attitudes of the community in Selangor. This shows that Selangor's action in this aspect should be exemplified by other states in Malaysia in line with Environmental Quality Act 1974, which is administered by the Department of Environment. However, e-waste management practices among respondents in Selangor were at a medium level overall, but could be improved over time. The results of this study indicate that most of the respondents are aware of the proper method of e-waste disposal, as they had been informed about e-waste's negative impact on the environment. However, due to the incomplete e-waste collection infrastructure in 
some places, the respondents tend to dispose of e-waste in the river and accumulate it together with other solid waste. Therefore, the collection of information on the public's actual knowledge, attitudes and practices in managing e-waste are a need for the country to improve the process of information dissemination and also examine the constraints imposed by the community on the implementation of more practical and sustainable ewaste management and future studies covering the entire population of Malaysian are necessary to compare the awareness of the e-waste disposal of communities in every fourteen Malaysia's state to build an action plan.

\section{Acknowledgements}

This research was carried out with the assistance of the University Research Grant (GPU 2016-0162-106-01). The authors wish to express their gratitude to UPSI who provided the research fund and the parties involved in this research.

\section{ORCID}

Hanifah Mahat (iD https://orcid.org/0000-0003-0756-6907

Mohmadisa Hashim (iD https://orcid.org/0000-0001-6364-7918

Nasir Nayan (1) https://orcid.org/0000-0001-8812-4320

Yazid Saleh (iD https://orcid.org/0000-0003-1603-9025

Saiyidatina Balkhis Norkhaidi (ㅇ) https://orcid.org/0000-0002-4571-4619

\section{References}

Abul Hasan, M., Abbasi, T. A., Mahapatra, R. P., Ahmed, S., \& Abbasi, M. S., (2010). Ewaste management and hazardous effect on environment. In Proceedings of the 4th National Conference; INDIACom-2010 Computing for Nation Development.

Afroz, R., Masud, M. M., Akhtar, R., \&-Duasa, J. B. (2012). Public environmental awareness and performance in Kuala Lumpur city, Malaysia: A case study on household electrical and electronic equipment. Environment and Urbanization Asia, 3(2), 385-396.

Ahmad Faisal, A., Mohd Bakri, I., Siti Nur Awanis, M. Z., \& Rusamah, A. J. (2014). Ewaste management: An emerging global crisis and the Malaysian scenario. International Journal of Environmental Sciences, 4(4), 444-457.

Akhtar, R., Masud, M. M., \& Afroz, R. (2014). Household perception and recycling behaviour on electronic waste management: A case study of Kuala Lumpur, Malaysia. Malaysian Journal of Science, 33(1), 32-41.

Barbier, E. B. (1987). The concept of sustainable economic development. Environmental Conservation, 14(2), 101-110.

Bhattacherjee, A. (2012). Social science research: Principles, methods and practices. University of South Florida, Tampa, USA.

Chibunna, J. B., Siwar, C., Begum, R. A., \& Mohamed, A. F. (2012). The challenges of e-waste management among institutions: A case study of UKM. Procedia-Social and Behavioral Sciences, 59, 644-649

Department of National Solid Waste Management. (2015). Pengasingan sisa pepejal di punca. Jabatan Pengurusan Sisa Pepejal Negara, Putrajaya, Malaysia. Retrieved from 
http://jpspn.kpkt.gov.my/index.php/pages/view/127

Department of Statistics Malaysia. (2010). Buku tahunan perangkaan Malaysia. Jabatan Perangkaan Malaysia, Putrajaya, Malaysia.

Dourish, P., \& Bellotti, V. (1992). Awareness and coordination in shared workspaces. In Proceedings of the 1992 ACM conference on computer-supported cooperative work (pp. 107-114). New York, USA.

Echegaray, F., \& Hansstein, F. V. (2017). Assessing the intention-behavior gap in electronic waste recycling: The case of Brazil. Journal of Cleaner Production, 142(Part 1), 180-190.

Eckman, K., \& Walker, R. (2008). Knowledge, attitudes and practice (KAP) surveysummary report for the Duluth Lakeside stormwater reduction project (LSRP). Water Resources Center, University of Minnesota, USA. Retrieved from https://conservancy.umn.edu/bitstream/handle/11299/182370/cfans_asset 114355.pdf ? sequence $=1$

Fatihah, S., Rakmi, A. R., Arij, Y., \& Mohd Shahbudin, M. (2014). E-waste management scenarios in Malaysia. Journal of Waste Management. doi: 10.1155/2014/609169

Hanifah, M., Yazid, S., Mohmadisa, H., \& Nasir, N. (2016). Model development on awareness of education for sustainable schools development in Malaysia. Indonesian Journal of Geography, 48(1), 39-48.

Henley, S. H. A. (1984). Unconscious perception re-revisited: A comment on Merikle's (1982) paper. Bulletin of the Psychonomic Society, 22(2), 121-124.

Ho, S. T., Tong, D. Y. K., Ahmed, E. M., \& Lee, C. T. (2015). E-waste management practices of households in Melaka. International Journal of Environmental Science and Development, 6(11), 811-817.

Huang, P., Zhang, X., \& Deng, X. (2006). Survey and analysis of public environmental awareness and performance in Ningbo, China: A case study on household electrical and electrical equipment. Journal of Cleaner Production, 14(18), 1635-1643.

Ibitz, A. (2012). Environmental policy coordination in ASEAN: The case of waste from electrical and electronic equipment. Austrian Journal of South-East Asian Studies, 5(1), 30-51.

Kalana, J. A. (2010). Electrical and electrnic waste management practice by households in Shah alam, Selangor, Malaysia. International Journal of Environmental Science, 1(2), 132-144.

Krejcie, R. V., \& Morgan, D. W. (1971). Determining sample size for research activities. Educational and Psychological Measurement, 30(3), 607-610.

Kwatra, S., Pandey, S., \& Sharma, S. (2014). Understanding public knowledge and awareness on e-waste in an urban setting in India. Management of Environmental Quality, 25(6), 752-765.

Lance, C. E., Butts, M. M., \& Michels. L. C. (2006). The sources of four commonly reported cutoff criteria what did they really say? Organizational Research Methods, 9(2), 202-220.

Landell, K. (1997). Management by menu (1st ed.). London, UK: Wiley and Sons Inc.

Malaysia Department of Environment. (2013). E-sisa. Kementerian sumber asli dan alam sekitar, Putrajaya, Malaysia.

Merikle. P. M. (1984). Toward a definition of awareness. Bulletin of the Psychonomic Society, 22(5), 449-450.

Muaz, H., \& Mohamed, H. H. (2008). E-waste: Ethical implications for education and research. IIUM Engineering Journal, 9(2), 11-26.

Muukkonen, H., Kosonen, K., Marttiin, P., Vesikivi, P., Kaistinen, J., \& Nyman, G. (2013). Pedagogical design for knowledge creating inquiry in customer projects. Knowledge Management \& E-Learning, 5(3), 278-297. 
Norazli, O., Roslina, M., Noor Ezlin, A. B., \& Muhd Noor, M. Y. (2015). Developing an integrated electronic waste management approach in Malaysia. Journal of Advanced Research in Business and Management Studies, 1(1), 5-13.

Norizan, E., Nordin, A. R., \& Mohd Ali, S. (2010). Kajian tinjauan (secara kuantitatif). Kuala Lumpur, MY: McGraw-Hill.

Nur Sumaiyyah, S., Gautam, L. S., \& Mohd Badruddin, M. Y. (2015). Current waste generation of e-waste and challenges in developing countries. An overview. Malaysian Journal of Civil Engineering, 27(1), 110-120.

Okoye, A., \& Odoh, C. (2014). Assessment of the level of awareness of e-waste management and concern for the environment amongst the populace in Onitsha, Soustheastern Nigeria. Journal of Environmental Protection, 5(2), 120-134.

Pinfield, G. (1996). Beyond sustainability indicators. Local Environment, 1(2), 151-163.

Puckett, J., Byster, L., Westervelt, S., Gutierrez, R., Davis, S., Hussain, A., \& Dutta, M. (2002). Exporting harm: The high-tech trashing of Asia. The Basel Action Network (BAN), Seattle, WA, USA.

Robinson, B., H. (2009). E-waste: An assessment of global production and environmental impacts. Science of the Total Environment, 408(2), 183-191.

Sabouhi, F., Babaee, S., Naji, H., \& Zadeh, A. H. (2011). Knowledge, awareness, attitudes and practice about hypertension in hypertensive patients referring to public health care centers in Khoor \& Biabanak. Iranian Journal of Nursing and Midwifery Research, 16(1), 34-40.

Salerno, S., Nunziante, A., \& Santoro, G. (2014). Competences and knowledge: Keyfactors in the smart city of the future. Knowledge Management \& E-Learning, 6(4), 356-376.

Schwartz, N. E. (1976). Nutrition knowledge, attitudes and practices of Canadian public health nurses. Journal of Nutrition Education, 8(1), 28-31.

Selangor District Government Portal. (2016). Selangor district maps. Retrieved from http://jpbdselangor.gov.my/214-perkhidmatan/perkhidmatan/114-peta.html

Shahrom, M. Z., Wan Hamidon, W. B., Rahmah, E., Noor Ezlin, A. B., Nuraini, K. S., \& Azami, Z. F. (2009). Kaji selidik pendidikan alam sekitar dan keperluan kepada pembangunan lestari dalam proses pengajaran dan pembelajaran. Paper presented at Seminar Pendidikan Kejuruteraan dan Alam Bina. Universiti Kebangsaan Malaysia.

Sivathanu, B. (2016). User's perspective: Knowledge and attitude towards e-waste. International Journal of Applied Environmental Sciences, 11(2), 413-423.

Starke, L. (1990). Signs of hope: Working towards our common future. New York, NY: Oxford University Press.

Tarawneh, A., \& Saidan, M. (2013). Household's awareness, behaviours and willingness to participate in e-waste management in Jordan. International Journal of Ecosystem, $3(5), 124-131$.

United States Environmental Protection Agency (USEPA). (2011). Electronics waste management in the United States through 2009 (EPA 530-R-11-002). Washington, DC: Office of Resource Conservation and Recovery.

Wright, R. T., \& Nebel, B. J. (2005). Environmental science toward a sustainable future (9th ed.). Upper Saddle River, NJ: Pearson Prentice Hall.

Zainudin, A. (2010). Research methodology for business and social science. University Publication Centre, UiTM, Shah Alam, Malaysia. 